UDC 662.749 .38

\author{
I. Krutko, I. Danylo, V. Kaulin
}

\title{
KINETICS OF AZODICARBONAMIDE DECOMPOSITION IN THE PRESENCE OF AN INITIATOR FOR OBTAINING SOLID FOAMS
}

\author{
Donetsk National Technical University, Pokrovsk, Ukraine
}

\begin{abstract}
The kinetics of decomposition of azodicarbonamide, an exothermic chemical blowing agent, which is used for obtaining solid foams, was investigated. It was shown that the modified coal tar pitch can be used as a polymer matrix to produce foamed pitch composite materials. The decomposition temperature of azodicarbonamide is approximately 200$210^{\circ} \mathrm{C}$. Such a decomposition temperature is too high to foam a modified coal tar pitch due to a change in its rheological properties. The azodicarbonamide decomposition temperature can be reduced by adding initiators. $\mathrm{Zn}$ stearate, Ca stearate, their mixture and polyvinylchloride were used as initiators. The influence of the initiators on the kinetics of azodicarbonamide-initiator decomposition at temperatures of $130-150^{\circ} \mathrm{C}$ was investigated. The induction period, the time of reaching the maximum decomposition degree and the decomposition rate of the azodicarbonamide-initiator have been determined as a function of the temperature and the initiator amount. A maximum rate of mixture decomposition was observed in the case of $\mathrm{Zn}$ stearate; the addition of binary initiator $\mathrm{Zn}$ stearate/Ca stearate decelerates the process. The use of polyvinylchloride as an initiator is characterized by very low rates. The comparison of the decomposition degree for various initiators in isothermal conditions revealed that $\mathrm{Zn}$ stearate is the most active initiator. It has been established that there is a line of the optimal $\mathrm{Zn}$ stearate amount to reach the maximum decomposition degree at temperatures of $130-150^{\circ} \mathrm{C}$ for the complex blowing agent azodicarbonamide- $\mathrm{Zn}$ stearate. The gas number of the complex blowing agent, azodicarbonamide- $\mathrm{Zn}$ stearate with an optimal composition has been determined at 140 and $150^{\circ} \mathrm{C}$.
\end{abstract}

Keywords: azodicarbonamide, blowing agent, initiator, kinetics, decomposition, zinc stearate, solid foams.

DOI: $10.32434 / 0321-4095-2019-122-1-26-34$

\section{Introduction}

Solid foams (foam composites) are heterogeneous systems in which the dispersion phase is gas and the dispersion medium is a polymer matrix. Foam composites are effective constructive materials and suitable for use in various industries.

In work [1], it was shown that modified coal tar pitch (CTP) can be used as a polymer matrix to produce foamed pitch composite materials. Modified CTP is a product of low temperature modification of CTP by active polymers; it has a number of properties that correspond to amorphous polymers. Modified CTP (MCTP) has a viscosity of 55$190 \mathrm{~Pa} \cdot \mathrm{s}$ in the temperature range of $125-155^{\circ} \mathrm{C}[2,3]$.

Both physical blowing agents (PBA) and chemical blowing agents (ChBA) are used to foam the polymers. PBAs release the gas that foams the polymer melt due to the change in its aggregate state or due to the phase redistribution of the gaseous component. PBAs are used to obtain polymeric foam based on polymers of low viscosity (up to $10 \mathrm{~Pa} \cdot \mathrm{s}$ ).

Chemical blowing agents are substances and mixtures that release gas as a result of chemical processes of thermal decomposition or due to various chemical reactions.

When choosing ChBA, it is considered a number of requirements: the decomposition temperature of ChBA should be in the temperature range used for the processing of polymers; the ChBA decomposition rate should not be too high; gas output (gas number) should be high; decomposition products should be harmless to the environment. 
According to the thermodynamic characteristics, two types of ChBAs can be distinguished, the decomposition process of which is exothermic or endothermic.

One of the most common ChBA is azodicarbonamide $\mathrm{NH}_{2} \mathrm{CON}=\mathrm{NCONH}_{2}$, it belongs to the main types of exothermic ChBAs in the production of foam composites.

Exothermic ChBAs have a narrower range of decomposition temperatures (a wide processing temperature range) and give a higher yield of gas than endothermic ones [4]. It is assumed [5] that exothermic ChBAs are more effective in reducing the density and strengthening the breaking strength than endothermic foaming agents.

The decomposition temperature of azodicarbonamide (ADCA) exceeds $195^{\circ} \mathrm{C}$ and is approximately $200-210^{\circ} \mathrm{C}$ [6]. Such a decomposition temperature [3] is too high to foam a modified CTP due to a change in its rheological properties [3].

The foaming process is determined by the pitchpolymeric matrix viscosity. At temperatures of 130$150^{\circ} \mathrm{C}$, the CTP is in a highly elastic and viscousfluid state; that is, it has a viscosity that provides the foam formation (viscosity of 55-190 Pa.s). At temperatures above $195^{\circ} \mathrm{C}$, modified CTP shows the Newtonian flow; that means, it has a completely destroyed structure [3], and it is also subject to thermo-oxidative degradation.

The ADCA decomposition temperature can be reduced by adding initiators. Usually oxides and salts of metals of the 2nd and 3rd groups of the periodic system (zinc and calcium) are used as ADCA initiators [7]. The initiators were $\mathrm{Zn}$ stearate $\left(\mathrm{ZnSt}_{2}\right)$, Ca stearate $\left(\mathrm{CaSt}_{2}\right)$, a $\mathrm{Ca} / \mathrm{Zn}$ stearates mixture, which are also modified CTP thermostabilizers. In addition, polyvinyl chloride (PVC) was studied as an initiator. PVC is also used for modification of CTP. In the coarse PVC dehydrochlorination, the hydrogen chloride is released. It, to a greater or lesser extent, can intensify the ADCA decomposition.

One of the most important parameters in the pitch-polymeric matrix foaming process is the rate and fullness of blowing agent decomposition. Thus, this work is aimed at studying the ADCA decomposition kinetics in the presence of initiators $\left(\mathrm{ZnSt}_{2}, \mathrm{CaSt}_{2}, \mathrm{Ca} / \mathrm{Zn}\right.$ stearates mixture, PVC) to obtain foam-composites based on MCTP.

\section{Materials and methods}

The following materials were used for the study.

ADCA (CAS: $123-77-3, \mathrm{NH}_{2} \mathrm{CON}=\mathrm{NCONH}_{2}$ ) is a yellow-orange odorless crystalline substance. The content of the main substance is $95 \%$. The decomposition temperature is $210^{\circ} \mathrm{C}$; the gas number is $218 \mathrm{~cm}^{3} / \mathrm{g}$.

When heated, ADCA decomposes with the release of molecular nitrogen (mainly) and a small amount of ammonia. The optimum decomposition temperature is $210^{\circ} \mathrm{C}$ and above, the reaction is exothermic and autocatalytic [7].

Calcium stearate (CAS: 1592-23-0, $\left(\mathrm{C}_{17} \mathrm{H}_{35} \mathrm{COO}\right)_{2} \mathrm{Ca}$ or $\left.\mathrm{CaSt}_{2}\right)$ is a white powder. The content of calcium stearate is $98 \%$, the melting point is $150^{\circ} \mathrm{C}$.

Zinc stearate (CAS: $557-05-1,\left(\mathrm{C}_{17} \mathrm{H}_{35} \mathrm{COO}\right)_{2} \mathrm{Zn}$ or $\left.\mathrm{ZnSt}_{2}\right)$ is a white amorphous powder. The content of zinc is $10.1 \%$, the melting point is $130^{\circ} \mathrm{C}$.

Polyvinyl chloride $\mathrm{C}-6370-\mathrm{K}$ is a homogeneous white powder. The bulk density of the powder is $0.55 \mathrm{~g} / \mathrm{cm}^{3}$; the $\mathrm{K}_{\mathrm{F}}$ constant is 63 . PVC is a finely dispersed powder with a particle size of 100$200 \mu \mathrm{m}$, it belongs to the thermoplastics [8]. The density is $1.35-1.40 \mathrm{~g} / \mathrm{cm}^{3}$. PVC melting point (with destruction) is $150-220^{\circ} \mathrm{C}$.

The ADCA decomposition kinetics was studied under isothermal conditions in the presence of $\mathrm{ZnSt}_{2}$, $\mathrm{CaSt}_{2}, \mathrm{ZnSt}_{2} / \mathrm{CaSt}_{2}$ mixture and PVC. The used initiator amount varied from 0.12 to 1.0 (in weight part to 1 weight part of ADCA). The temperature varied in the range of $130-150^{\circ} \mathrm{C}$.

The procedure of studying the kinetics of blowing agent decomposition in the presence of the initiator involves several stages. The first stage is the preparation of ADCA and initiators mixture which includes the crushing the blowing agent components and their dispersion mixing in the given ratio. This is necessary to increase the contact area surface between ADCA and initiator particles and their uniform distribution in the reaction mass as well as improve the heat transfer conditions during heating. The second stage is the heating of porcelain boats with experimental sample weight $(2.0000 \mathrm{~g})$ in an air thermostat under isothermal conditions at a constant temperature $\left(130,140\right.$ and $\left.150^{\circ} \mathrm{C}\right)$ during $10,15,30$ or 60 minutes. At this stage, it is very important to keep the same conditions for research: the same thickness of the layer and the weight of each ADCA-initiator. The decomposition degree of the ADCA-initiator mixture (complex blowing agent-CBA) was determined by the following formula:

$$
\mathrm{D}=\frac{\left(\mathrm{m}_{1}-\mathrm{m}_{2}\right)}{\mathrm{m}_{1}} \cdot 100 \%,
$$

where $\mathrm{D}$ is the decomposition degree of $\mathrm{ADCA}-$ initiator mixture (CBA) (in \%); $\mathrm{m}_{1}$ is the initial 
sample weight $(\mathrm{g})$; and $\mathrm{m}_{2}$ is the sample weight after heating in thermostat $(\mathrm{g})$.

The gas number of the selected CBA was determined too. The procedure of determining the CBA gas number is as follows. CBA sample $(0.25 \mathrm{~g})$ was heated in a reaction flask in an oil bath. The rate of the temperature rising from 20 to $150^{\circ} \mathrm{C}$ did not exceed $5^{\circ} \mathrm{C} / \mathrm{min}$. After reaching the maximum temperature, the heating was stopped and CBA sample was maintained at a given temperature until the blowing agent was decomposed. After the reaction flask cooling, when the temperature in the reaction tube and in the burette shirt is equal, the released gas volume was measured. The gas volume was recalculated to normal conditions and the gas number $(\mathrm{ml} / \mathrm{g})$ was calculated by the formula:

$$
X=\frac{V}{G},
$$

where $\mathrm{V}$ is the released gas volume under normal conditions ( $\mathrm{ml}$ ); and $\mathrm{G}$ is the CBA sample $(\mathrm{g})$.

\section{Theory}

It is known that ADCA is an exothermic blowing agent [7]. The decomposition reaction is autocatalytic since the reaction products can react with unreacted ADCA, thereby increasing the gas formation rate. The released heat amount during decomposition of ADCA amounts to $86 \mathrm{cal} / \mathrm{g}$ (i.e. $10 \mathrm{kcal} / \mathrm{mol})$.

ADCA meets most requirements for the blowing agent, in particular, the requirements for the decomposition temperature, the gas releasing level, the gas composition, the ease of dispersion, storage stability, non-toxicity and cost. In addition, this substance is self-extinguishing in contact with an open flame and does not support burning of the polymer. ADCA is the most economical of all industrial blowing agents [7].

The ADCA decomposition mechanism is complex and not fully understood. The main chemical transformations that accompany the ADCA decomposition are schematically presented in Figure 1 [9].

The ADCA thermal decomposition $[9,10]$ proceeds in two stages. At the first stage (at the temperatures of $180-220^{\circ} \mathrm{C}$ ), the decomposition products are carbon monoxide, nitrogen and urea. At the second stage, which corresponds to a wider range of temperatures $\left(220-320^{\circ} \mathrm{C}\right)$, gaseous ammonia together with solid isocyanic acid are formed, the latter is the product of urea decomposition. The material does not completely decompose into gaseous products. In the course of decomposition, $35 \%$ of gas, $40 \%$ of solid residue and $25 \%$ of sublimate are formed. The gas consists of $65 \%$ nitrogen, $32 \%$ carbon monoxide and $3 \%$ other gases, including ammonia and carbon dioxide. Ammonia is mainly formed at high temperatures.

It is known that the ADCA decomposition temperature can be reduced by the introduction of initiators - salts of zinc and calcium. Some researchers [11,12] assumed that the interaction of ADCA with salts of calcium or zinc yields the corresponding salts of azodicarboxylic acid which act as the initiator of thermal decomposition. Also, the activation mechanism of the ADCA decomposition process is the acid-base interaction by Lewis where the metal of activating additive acts as a Lewis acid, being an electron acceptor, and ADCA acts as the base, that is, it is an electron pair donor. It was also assumed [13] that metals, which have filled pre-outer d-electron orbitals, probably can form $\pi$-complexes which include ADCA molecules as ligands. The formation of $\pi$-complexes leads to a decrease in the electron density between nitrogen atoms of the azo-group and carbon; as a result, a break of $-\mathrm{C}-\mathrm{N}=$ bond is facilitated.

\section{Results and discussion}

The ADCA decomposition kinetics was investigated for different types and contents of initiators in isothermal conditions. The research temperature varied in the range of $130-150^{\circ} \mathrm{C} . \mathrm{ZnSt}_{2}$, PVC and the binary initiator, $\mathrm{ZnSt}_{2}$ and $\mathrm{CaSt}_{2}$ mixture (at the ratio $\mathrm{ZnSt}_{2}: \mathrm{CaSt}_{2}=2: 1$ ) were used as initiators. The amount of initiator in the CBA varied from 0.12 to 1.0 weight part in relation to 1 weight part of ADCA.

The kinetic curves of CBA (ADCA- $\left.\mathrm{ZnSt}_{2}\right)$ decomposition for the temperatures of $130-150^{\circ} \mathrm{C}$

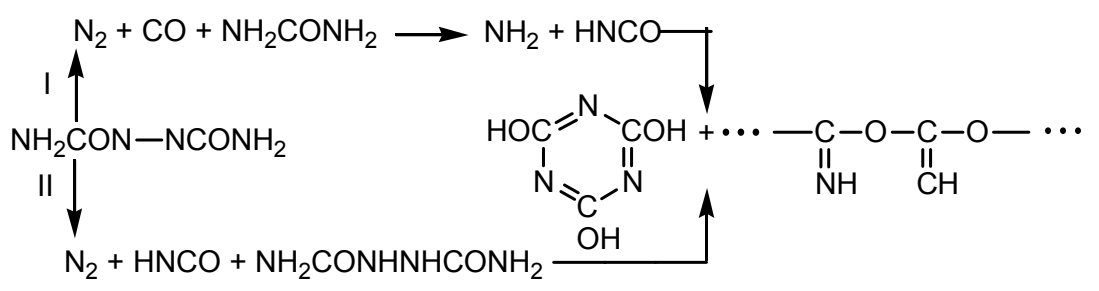

Fig. 1. The chemism of ADCA thermal decomposition [9] 


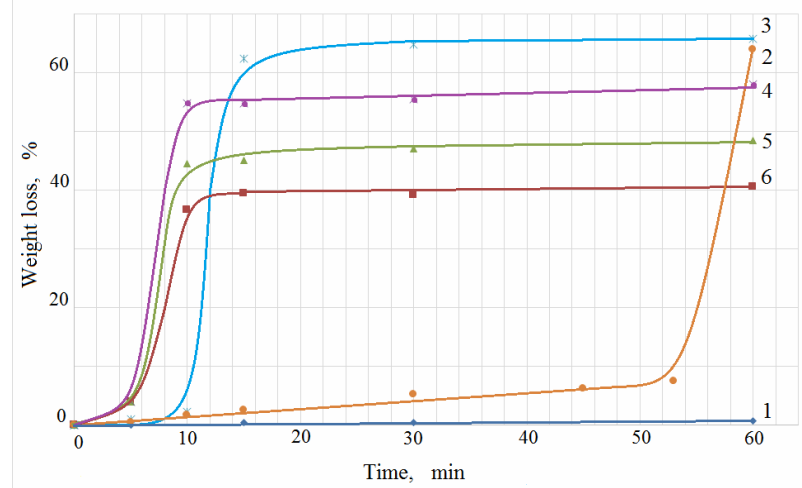

Fig. 2. Kinetic curves of CBA (ADCA-ZnSt ${ }_{2}$ ) decomposition at $150^{\circ} \mathrm{C}$. The ratio ADCA: $\mathrm{ZnSt}_{2}$ (in weight part): (1) - 1:0; (2) $-1: 0.12$; (3) - 1:0.25; (4) - 1:0.50; (5) - 1:0.75; (6) - $1: 1$

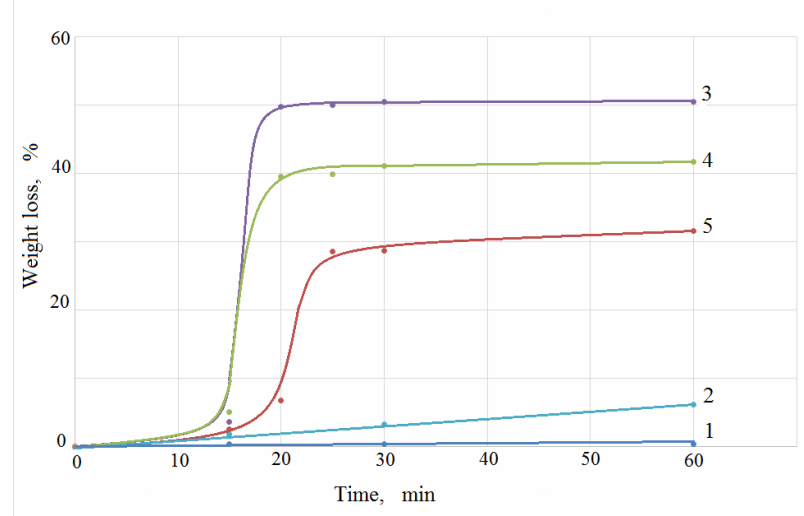

Fig. 3. Kinetic curves of CBA ( $\mathrm{ADCA}-\mathrm{ZnSt}_{2}$ ) decomposition at $140^{\circ} \mathrm{C}$. The ratio ADCA: $\mathrm{ZnSt}_{2}$ (in weight part): (1) - 1:0; (2) $-1: 0.25$; (3) - 1:0.50; (4) - 1:0.75; (5) - $1: 1$

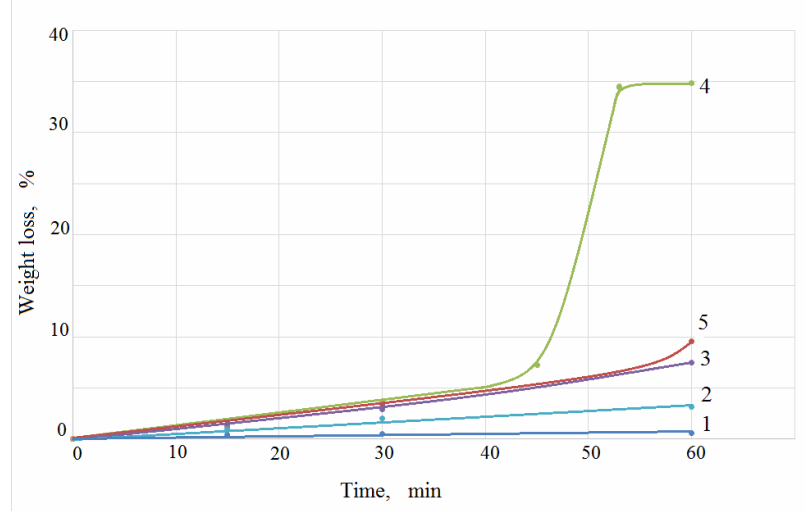

Fig. 4. Kinetic curves of CBA (ADCA- $\mathrm{ZnSt}_{2}$ ) decomposition at $130^{\circ} \mathrm{C}$. Ratio ADCA: $\mathrm{ZnSt}_{2}$ (in weight part): (1) - 1:0; (2) $-1: 0.25$; (3) - 1:0.50; (4) - 1:0.75; (5) - $1: 1$ are shown in Figs. 2-4. At the initial stage, there is a certain induction period, the duration of which decreases with increasing the temperature. Then, there is a sharp increase in the decomposition rate due to chemical reactions after which the rate is reduced and the gas separation process is completed.

The induction period at $150^{\circ} \mathrm{C}$ for the $\mathrm{ADCA}-$ $\mathrm{ZnSt}_{2}$ system depends on the amount of $\mathrm{ZnSt}_{2}$; the less the quantity of the initiator, the more is the induction period (Fig. 2). The induction period is 5; 10 and 50 minutes at the initiator amount (in weight part to 1 weight part of ADCA) of $0.5-1.0 ; 0.25$ and 0.12 , respectively. The decomposition process proceeds at a high rate and ends in 10 and 15 minutes at the initiator amount of $0.5-1.0$ and 0.25 , respectively.

Reducing the temperature to $140^{\circ} \mathrm{C}$ (Fig. 3) increases the induction period and the time which is needed to achieve the maximum degree of the CBA $\left(\mathrm{ADCA}-\mathrm{ZnSt}_{2}\right)$ decomposition. The induction period at $140^{\circ} \mathrm{C}$ for the system $\mathrm{ADCA}-\mathrm{ZnSt}_{2}$ is about 15 minutes and more than 60 minutes at the $\mathrm{ZnSt}_{2}$ amount (in weight part to 1 weight part of ADCA) of $0.5-1.0$ and 0.25 , respectively. The decomposition process proceeds at a high rate; it ends after 20 and 25 minutes at the initiator amount of $0.5-1.0$ and 0.25 , respectively.

Further reducing the temperature to $130^{\circ} \mathrm{C}$ (Fig. 4) sharply reduces the decomposition rate and increases the induction period for more than 60 minutes. There is an induction period of about 40 minutes only at the amount of $\mathrm{ZnSt}_{2} 0.75$ weight part to 1 weight part ADCA; the decomposition ends in 50 minutes.

For the binary initiator $\mathrm{ZnSt}_{2} / \mathrm{CaSt}_{2}$ only at $150^{\circ} \mathrm{C}$ (Fig. 5) and the $\mathrm{ZnSt}_{2} / \mathrm{CaSt}_{2}$ initiator amount

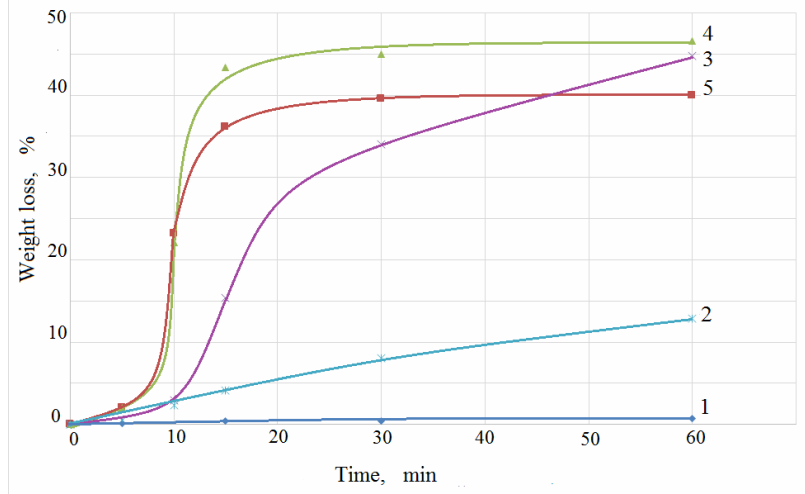

Fig. 5. Kinetic curves of CBA (ADCA- $\mathrm{ZnSt}_{2} / \mathrm{CaSt}_{2}$ ) decomposition at $150^{\circ} \mathrm{C}$. Ratio ADCA: $\mathrm{ZnSt}_{2} / \mathrm{CaSt}_{2}$ (in weight part): (1) - 1:0; (2) - 1:0.25; (3) - 1:0.50; (4) $-1: 0.75 ;(5)-1: 1$ 


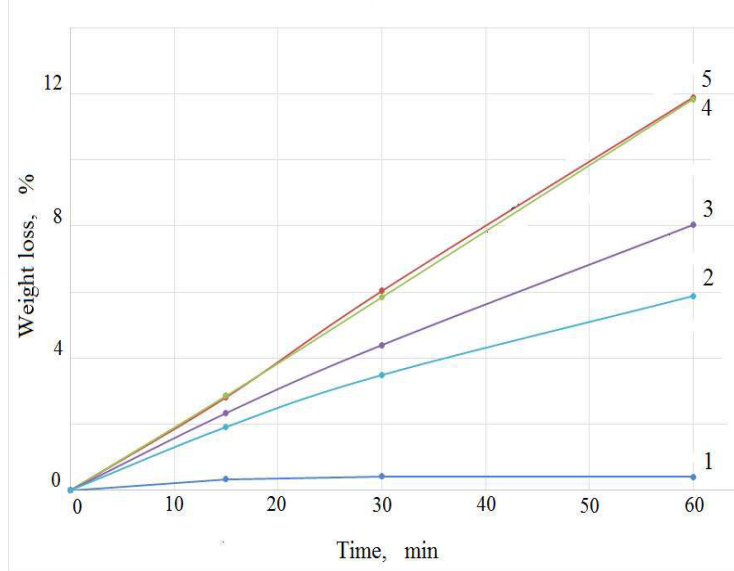

Fig. 6. Kinetic curves of CBA (ADCA- $\mathrm{ZnSt}_{2} / \mathrm{CaSt}_{2}$ ) decomposition at $140^{\circ} \mathrm{C}$. Ratio ADCA: $\mathrm{ZnSt}_{2} / \mathrm{CaSt}_{2}$ (in weight part): (1) - 1:0; (2) - 1:0.25; (3) - 1:0.50;

$$
\text { (4) }-1: 0.75 ;(5)-1: 1
$$

of $0.5-1.0$ weight part to 1 weight part ADCA, there is an induction period of 5 minutes and high decomposition rate, the decomposition ends in 20 minutes.

A decrease in the temperature to $130-140^{\circ} \mathrm{C}$ (Figs. 6,7) changes the decomposition kinetics of $\mathrm{ADCA}-\mathrm{ZnSt}_{2} / \mathrm{CaSt}_{2}$ mixture: the rate decreases sharply and the process does not end after 60 minutes. In addition, $\mathrm{ADCA}-\mathrm{ZnSt}_{2} / \mathrm{CaSt}_{2}$ mixture decomposition degree decreases by 3-8 times in comparison with the same initiator amount at $150^{\circ} \mathrm{C}$.

Figure 8 shows typical kinetic curves of ADTA decomposition (for temperatures of $130-150^{\circ} \mathrm{C}$ ) in the presence of PVC as an initiator. As can be seen, PVC is a weak initiator of the ADCA decomposition.

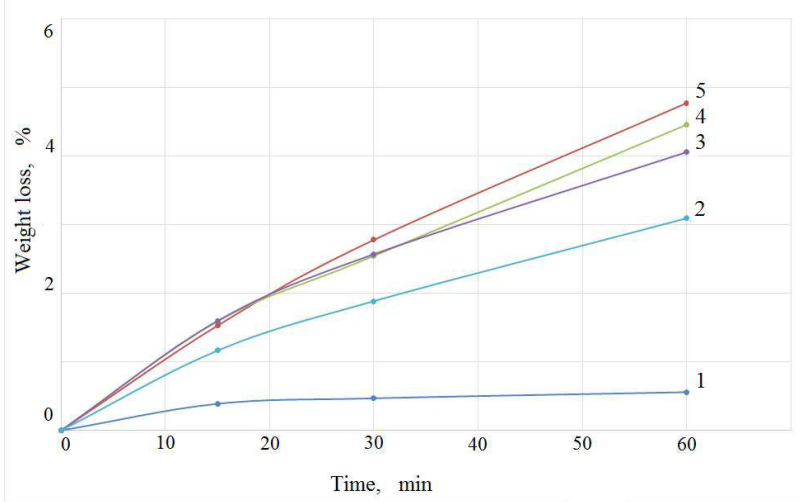

Fig. 7. Kinetic curves of CBA (ADCA- $\mathrm{ZnSt}_{2} / \mathrm{CaSt}_{2}$ ) decomposition at $130^{\circ} \mathrm{C}$. Ratio ADCA: $\mathrm{ZnSt}_{2} / \mathrm{CaSt}_{2}$ (in weight part): (1) - 1:0; (2) - 1:0.25; (3) - 1:0.50; (4) $-1: 0.75 ;(5)-1: 1$

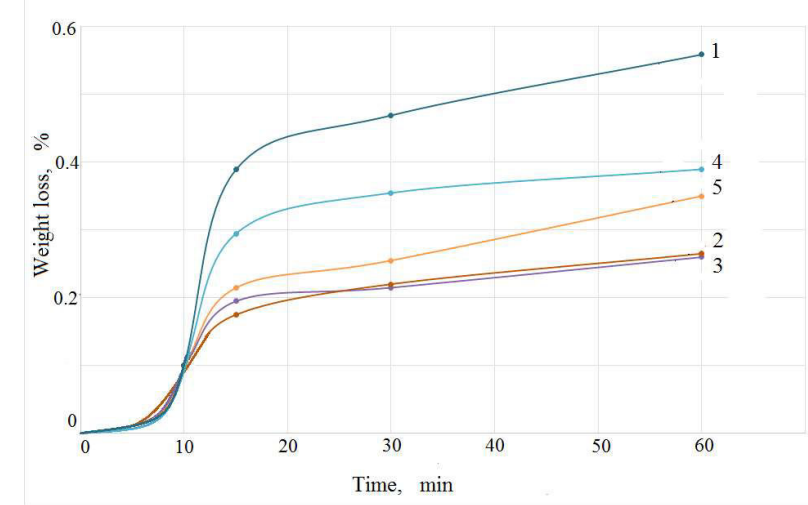

Fig. 8. Kinetic curves of CBA (ADCA-PVC) decomposition at $130^{\circ} \mathrm{C}$. Ratio ADCA:PVC (in weight part): (1) - 1:0; (2) $-1: 0.25$; (3) - 1:0.50; (4) - 1:0.75; (5) - 1:1

The dependence of the ADCA maximum decomposition rate at the temperature and activators amount after 60 minutes of heating

\begin{tabular}{c|c|c|c|c}
\hline Temperature, & The activator amount, weight & \multicolumn{3}{|c}{ The maximum decomposition rate, \%/min } \\
\cline { 3 - 5 }${ }^{0} \mathrm{C}$ & part to 1 weight part ADCA & ADCA-ZnSt & ADCA-ZnSt $/ \mathrm{CaSt}_{2}$ & ADCA-PVC \\
\hline \multirow{4}{*}{150} & 1 & 6.0 & 3.85 & 0.10 \\
\cline { 2 - 5 } & 0.75 & 10.0 & 6.25 & 0.09 \\
\cline { 2 - 5 } & 0.50 & 12.0 & 2.10 & 0.05 \\
\cline { 2 - 5 } & 0.25 & 14.0 & 0.28 & 0.12 \\
\cline { 2 - 5 } & 0.12 & 10.7 & - & - \\
\hline \multirow{4}{*}{140} & 1 & 15.0 & 0.21 & 0.01 \\
\cline { 2 - 5 } & 0.75 & 30.0 & 0.20 & 0.05 \\
\cline { 2 - 5 } & 0.50 & 30.0 & 0.13 & 0.03 \\
\hline \multirow{4}{*}{130} & 0.25 & 0.1 & 0.11 & 0.09 \\
\cline { 2 - 5 } & 1 & 0.65 & 0.10 & 0.06 \\
\cline { 2 - 5 } & 0.75 & 4.4 & 0.06 & 0.03 \\
\cline { 2 - 5 } & 0.5 & 0.1 & 0.08 & \\
\hline
\end{tabular}


In the range of $130-150^{\circ} \mathrm{C}$ and the PVC amount of 0.25-1.0 (in weight part) the maximum decomposition degree of ADCA-PVC mixture (for 60 minutes) ranges from 0.2 to $0.7 \%$.

Table shows the maximum decomposition rates of ADCA-initiator mixture depending on the temperature, type and amount of the initiator.

As can be seen from the Table, ADCA-initiator mixture decomposition rate depends on the temperature, the nature of initiator and its amount. Increasing the temperature in the investigated range $\left(130-150^{\circ} \mathrm{C}\right)$ results in an increase in the chemical reactions rate of $\mathrm{ADCA}$-initiator mixture decomposition. The maximum decomposition rates of the ADCA-initiator are observed for $\mathrm{ZnSt}_{2}$. The addition of the binary initiator $\mathrm{ZnSt}_{2} / \mathrm{CaSt}_{2}$

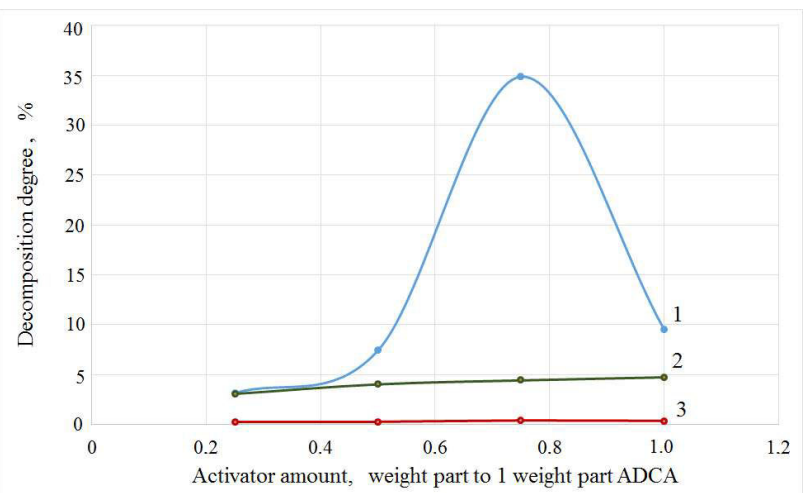

Fig. 9. The dependence of the CBA (ADCA-initiator) decomposition degree on the type and amount of initiator (in weight part to 1 weight part ADCA) under isothermal conditions $\left(130^{\circ} \mathrm{C}\right):(1)-\mathrm{ADCA}-\mathrm{ZnSt}_{2}$;

(2) $-\mathrm{ADCA}-\mathrm{ZnSt}_{2} / \mathrm{CaSt}_{2}$; (3) - ADCA-PVC

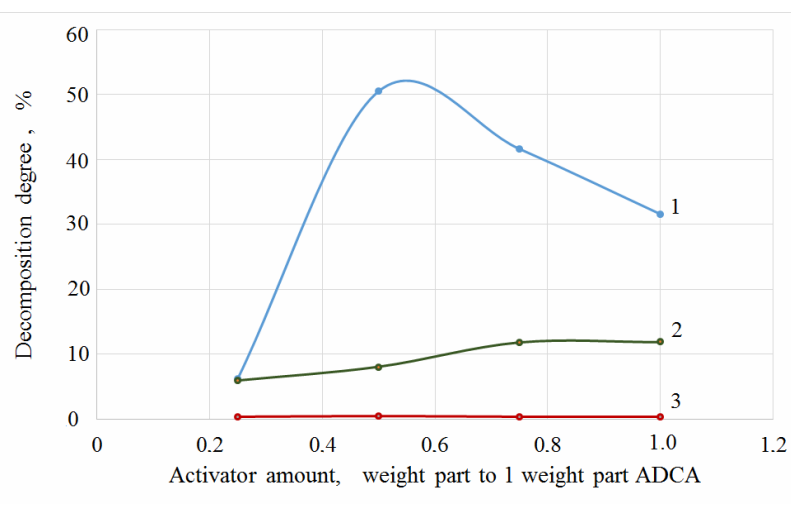

Fig. 10. The dependence of the CBA (ADCA-initiator) decomposition degree on the type and amount of initiator (in weight part to 1 weight part ADCA) under isothermal conditions $\left(140^{\circ} \mathrm{C}\right):(1)-\mathrm{ADCA}-\mathrm{ZnSt}_{2}$;

(2) $-\mathrm{ADCA}^{-} \mathrm{ZnSt}_{2} / \mathrm{CaSt}_{2}$; (3) - $\mathrm{ADCA}-\mathrm{PVC}$ decelerates the process, and the use of PVC as an initiator is characterized by very low rates.

A comparison of the decomposition degree (achieved after 60 minutes) for different initiators in isothermal conditions indicates that $\mathrm{ZnSt}_{2}$ is the most active initiator (Figs. 9-11). PVC has the least activity. The binary initiator $\mathrm{ZnSt}_{2} / \mathrm{CaSt}_{2}$ occupies an intermediate position in activity between $\mathrm{ZnSt}_{2}$ and PVC.

The $\mathrm{ADCA}-\mathrm{ZnSt}_{2}$ mixture decomposition degree depends on the $\mathrm{ZnSt}_{2}$ amount and temperature. An increase in the temperature leads to an increase in the mixture decomposition degree in the presence of $\mathrm{ZnSt}_{2}$. The dependence of the decomposition degree under isothermal conditions on the amount of initiator has a complex character with an extremum at certain values of the initiator. An increase in the temperature from 130 to $150^{\circ} \mathrm{C}$ decreases the amount of initiator $\mathrm{ZnSt}_{2}$ to achieve the maximum decomposition degree.

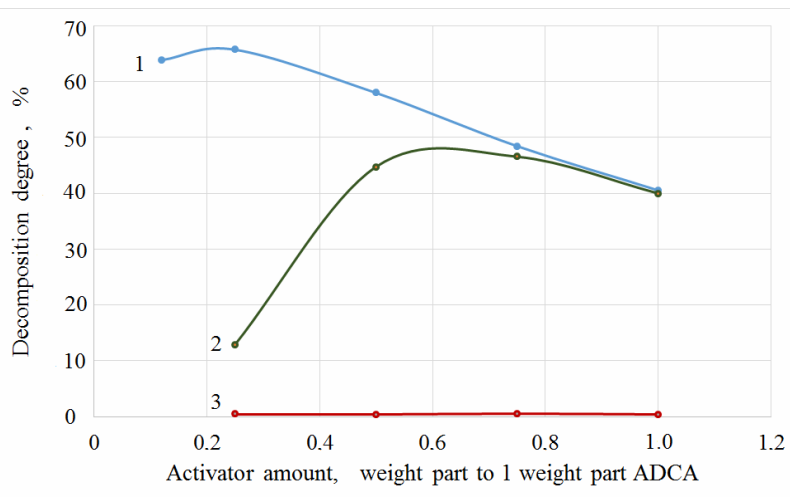

Fig. 11. The dependence of the CBA ADCA-initiator decomposition degree on the type and amount of initiator (in weight part to 1 weight part ADCA) under isothermal conditions $\left(150^{\circ} \mathrm{C}\right):(1)-\mathrm{ADCA}-\mathrm{ZnSt}_{2}$;

(2) $-\mathrm{ADCA}^{-} \mathrm{ZnSt}_{2} / \mathrm{CaSt}_{2}$; (3) - $\mathrm{ADCA}-\mathrm{PVC}$

Figure 12 shows the dependence of the CBA $\left(\mathrm{ADCA}-\mathrm{ZnSt}_{2}\right)$ decomposition degree on the temperature and amount of the initiator.

It can be observed from Fig. 12 that there is an extremum that corresponds to the maximum degree of CBA (ADCA- $\mathrm{ZnSt}_{2}$ ) decomposition for each temperature. With an increase in the temperature, $\mathrm{ZnSt}_{2}$ initiator amount decreases at each point of the maximum. That is, there is a line of initiator optimum amount to achieve the maximum of CBA $\left(\mathrm{ADCA}-\mathrm{ZnSt}_{2}\right.$ ) decomposition degree under isothermal conditions at $130-150^{\circ} \mathrm{C}$.

The dependences of the initiator $\left(\mathrm{ZnSt}_{2}\right)$ optimum amount and the maximum degree of CBA decomposition on temperature were derived as 


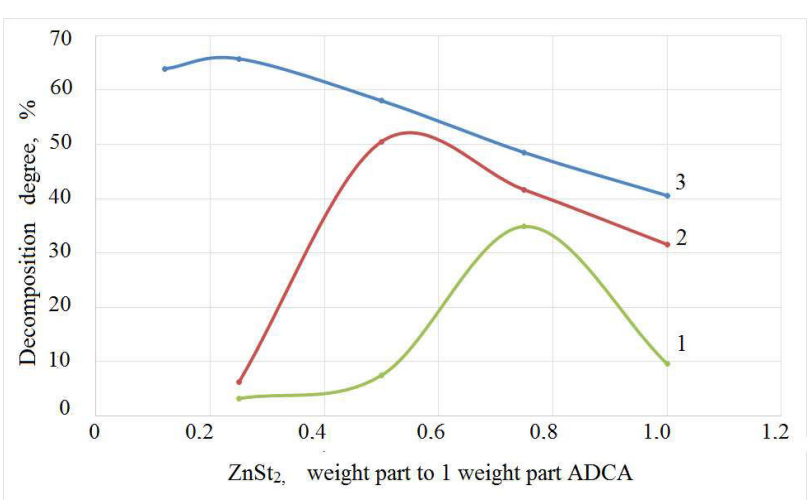

Fig. 12. The dependence of the CBA ADCA- $\mathrm{ZnSt}_{2}$ decomposition degree on the temperature and $\mathrm{ZnSt}_{2}$ amount (in weight part to 1 weight part ADCA): (1) $-130^{\circ} \mathrm{C}$; (2) $-140^{\circ} \mathrm{C} ;(3)-150^{\circ} \mathrm{C}$

follows:

$A_{D}=4-0.025 t ;$

$\mathrm{D}_{\mathrm{A}}=1.55 \mathrm{t}-165.98$,

where $A_{D}$ is the $\mathrm{ZnSt}_{2}$ amount to obtain the decomposition maximum degree $\mathrm{D}_{\mathrm{A}}$ (in weight part to 1.0 weight part $\mathrm{ADCA}) ; \mathrm{D}_{\mathrm{A}}$ is the CBA decomposition maximum degree at optimal $\mathrm{ZnSt}_{2}$ amount $(\%)$ and $\mathrm{t}$ is the temperature $\left({ }^{\circ} \mathrm{C}\right)$.

The gas numbers of the CBA $\left(\mathrm{ADCA}-\mathrm{ZnSt}_{2}\right)$ optimal composition at 140 and $150^{\circ} \mathrm{C}$ have been determined. They are equal to $148 \mathrm{~cm}^{3}\left(221 \mathrm{~cm}^{3}\right.$ in terms of ADCA) and $156 \mathrm{~cm}^{3}\left(195 \mathrm{~cm}^{3}\right.$ in terms of $\mathrm{ADCA})$ at $140^{\circ} \mathrm{C}\left(\mathrm{ADCA}: \mathrm{ZnSt}_{2}=1: 0.5\right)$ and at $150^{\circ} \mathrm{C}$ $\left(\mathrm{ADCA}: \mathrm{ZnSt}_{2}=1: 0.25\right)$, respectively.

\section{Conclusions}

The effects of initiators $\mathrm{ZnSt}_{2}, \mathrm{ZnSt}_{2} / \mathrm{CaSt}_{2}$ and $\mathrm{PVC}$ on the kinetics of ADCA-initiator decomposition at $130-150^{\circ} \mathrm{C}$ were investigated. The induction period, the time of reaching the maximum decomposition degree and the decomposition rate of the ADCA-initiator have been established as a function of the temperature and amount of the initiator. The maximum decomposition rate of $\mathrm{ADCA}-$ initiator mixture is observed for $\mathrm{ZnSt}_{2}$; the addition of the binary initiator $\mathrm{ZnSt}_{2} / \mathrm{CaSt}_{2}$ decelerates the process, and the use of PVC as an initiator is characterized by very low rates.

The ADCA-initiator mixture decomposition degree depends on the temperature, the nature of initiator and its amount. The most active initiator is $\mathrm{ZnSt}_{2}$. PVC shows the least activity. The binary initiator $\mathrm{ZnSt}_{2} / \mathrm{CaSt}_{2}$ occupies an intermediate position in activity between $\mathrm{ZnSt}_{2}$ and PVC. The $\mathrm{ADCA}-\mathrm{ZnSt}_{2}$ mixture decomposition degree is $65.8 \%$ at initiator amount of 0.25 (weight part) at $150^{\circ} \mathrm{C}$.

An increase in the temperature of the ADCA$\mathrm{ZnSt}_{2}$ mixture results to an increase in the decomposition degree and a decrease in the amount of $\mathrm{ZnSt}_{2}$ initiator to achieve maximum decomposition degree. There is a line of the optimal $\mathrm{ZnSt}_{2}$ amount to reach the maximum decomposition degree at 130$150^{\circ} \mathrm{C}$ for the CBA (ADCA- $\mathrm{ZnSt}_{2}$ ).

The equations have been derived which allow determining the optimal $\mathrm{ZnSt}_{2}$ initiator amount and maximum CBA decomposition degree depending on the temperature in the range of $130-150^{\circ} \mathrm{C}$. The gas number of the CBA (ADCA- $\mathrm{ZnSt}_{2}$ ) optimal composition has been determined at 140 and $150^{\circ} \mathrm{C}$.

\section{REFERENCES}

1. Крутько И.Г., Колбаса В.А. О возможности получения твердых пен на основе модифицированного каменноугольного пека // Наук. праці ДонНТУ. Сер. Хімія і хім. технол. - 2013. - № 2(21). - С.156-161.

2. Крутько І.Г., Каулін В.Ю. Теоретичні передумови використання кам'яновугільного пеку як полімерного матеріалу // Наук. праці ДонНТУ. Сер. Хімія і хім. технол. 2010. - № 15(163). - С.103-107.

3. Крутько І.Г., Каулін В.Ю., Сацюк К.О. Реологічні дослідження модифікованих кам'яновугільних пеків // Наук. праці ДонНТУ. Сер. Хімія і хім. технол. - 2011. - № 16(184). - C. $150-158$.

4. Lee S.T., Park C.B. Foam extrusion: principles and practice. - USA: CRC Press. - 2014. -624 p.

5. Bledzki A.K., Faruk O. Injection moulded microcellular wood fibre-polypropylene composites // Compos. A: Appl. Sci. Manufact. - 2006. - Vol.37. - P.1358-1367.

6. Effect of PVC resin and its additives on the decomposition temperature of a chemical blowing agent (azobisformamide) / A. Douibi, L. Gouissem, M. Guessoum, D. Benachour // Int. J. Eng. Technol. - 2014. - Vol.14. - No. 2. - P.60-64.

7. Цвайфель Х., Маер Р.Д., Шиллер М. Добавки к полимерам (справочник). - СПб: Профессия. - 2010. - 1142 с.

8. Власов С.В., Кандырин Л.Б., Кулезнев В.Н. Основы технологии переработки пластмасс. - М.: Химия. - 2004. $600 \mathrm{c}$.

9. Reyes-Labarta J.A., Marcilla A. Kinetic study of the decompositions involved in the thermal degradation of commercial azodicarbonamide // J. Appl. Polym. Sci. - 2008. - Vol.107. P.339-346,

10. Petchwattana N., Covavisaruch $S$. Influences of particle sizes and contents of chemical blowing agents on foaming wood plastic composites prepared from poly(vinyl chloride) and rice 
hull // Mater. Design. - 2011. - Vol.32. - P.2844-2850.

11. Аль-Малики Тахсин Али Саки. Влияние состава жестких поливинилхлоридных композиций на кинетику вспенивания азодикарбонамидом: Дис...канд. техн. наук: 05.17.06. - М.: МИТХТ. - 2016. - 119 с.

12. Кинетика термического разложения азосоединений / А.Я. Васин, Г.В. Макаров, Л.К. Маринина, З.А. Якушева // Извест. вузов «Химия и хим. технол.» - 1980. Т.23. - № 9. - С.1070-1074.

13. Гмызина Р.Н., Мишина И.М., Пугачева Л.А. Вспенивающие агенты для поливинилхлоридных пенопластов. М.: НИИТЕХХИМ. - 1984. - 42 с.

Received 18.09.2018

\section{КІНЕТИКА РОЗКЛАДАННЯ АЗОДИКАРБОНАМІДУ В ПРИСУТНОСТІ ІНІЩАТОРА ДЛЯ ОДЕРЖАННЯ ТВЕРДИХ ПІН}

\section{І.Г. Крутько, І.І. Данило, В.Ю. Каулін}

Досліджсено кінетику розкладання азодикарбонаміду екзотермічного хімічного газоутворювача, який використовується для одержання твердих пін. Як полімерна матриия для одержання спінених композиційних матеріалів може бути використаний модифікований кам'яновугільний пек. Температура розкладання азодикарбонаміду складає приблизно 200$210^{\circ}$ C. Така температура є занадто високою для спінювання модифікованого кам'яновугільного пеку через зміну його реологічних властивостей. Температура розкладання азодикарбонаміду може бути знижена шляхом додавання ініціаторів. Як ініціатори були використані Zn cтеарат, Са стеарат, їх суміш, а також полівінілхлорид. Досліджено вплив ініціаторів на кінетику розкладання суміші азодикарбонамід-ініціатор при температурах 130-150 С. Встановлено індукційний період, час досягнення максимального ступеня розкладання та швидкість розкладання суміші азодикарбонамід-ініціатор в залежності від температури і кількості ініціатора. Максимальна швидкість розкладання суміші спостерігається для Zn cmeapamy, додавання бінарного ініціатора Zn cmеарат/Ca cтеарат уповільнюе процес, а використання полівінілхлориду в якості ініціатора характеризується дуже малими швидкостями. Порівняння ступеня розкладання для різних ініціаторів в ізотермічних умовах показало, що найактивнішим ініціатором $є$ Zn cтеарат. Встановлено, щз для комплексного газоутворювача азодикарбонамід-стеарат Zn існує лінія оптимальної кількості стеарату Zn для досягнення максимального ступеня розкладання при температурах 130-150 C. Визначено газове число комплексного газоутворювача азодикарбонамід-стеарат Zn оптимального складу при 140 i $150^{\circ} \mathrm{C}$.

Ключові слова: азодикарбонамід, газоутворювач, ініціатор, кінетика, розкладання, стеарат цинку, тверді піни.

\section{KINETICS OF AZODICARBONAMIDE DECOMPOSITION IN THE PRESENCE OF AN INITIATOR FOR OBTAINING SOLID FOAMS}

\author{
I. Krutko *, I. Danylo, V. Kaulin \\ Donetsk National Technical University, Pokrovsk, Ukraine \\ *e-mail: poshukdoc@gmail.com
}

The kinetics of decomposition of azodicarbonamide, an exothermic chemical blowing agent, which is used for obtaining solid foams, was investigated. It was shown that the modified coal tar pitch can be used as a polymer matrix to produce foamed pitch composite materials. The decomposition temperature of azodicarbonamide is approximately $200-210^{\circ} \mathrm{C}$. Such a decomposition temperature is too high to foam a modified coal tar pitch due to a change in its rheological properties. The azodicarbonamide decomposition temperature can be reduced by adding initiators. $\mathrm{Zn}$ stearate, Ca stearate, their mixture and polyvinylchloride were used as initiators. The influence of the initiators on the kinetics of azodicarbonamide-initiator decomposition at temperatures of 130$150^{\circ} \mathrm{C}$ was investigated. The induction period, the time of reaching the maximum decomposition degree and the decomposition rate of the azodicarbonamide-initiator have been determined as a function of the temperature and the initiator amount. A maximum rate of mixture decomposition was observed in the case of Zn stearate; the addition of binary initiator Zn stearate/Ca stearate decelerates the process. The use of polyvinylchloride as an initiator is characterized by very low rates. The comparison of the decomposition degree for various initiators in isothermal conditions revealed that $Z n$ stearate is the most active initiator. It has been established that there is a line of the optimal $\mathrm{Zn}$ stearate amount to reach the maximum decomposition degree at temperatures of $130-150^{\circ} \mathrm{C}$ for the complex blowing agent azodicarbonamide-Zn stearate. The gas number of the complex blowing agent, azodicarbonamide-Zn stearate with an optimal composition has been determined at 140 and $150^{\circ} \mathrm{C}$.

Keywords: azodicarbonamide; blowing agent; initiator; kinetics; decomposition; zinc stearate; solid foams.

\section{REFERENCES}

1. Krutko I., Kolbasa V. O vozmozhnosti polucheniya tverdykh pen na osnove modifitsirovannogo kamennougolnogo peka [About the possibility of the preparation of solid foams based on modified coal tar pitch]. Naukovi Pratsi DonNTU, Seriya: Khimiya i Khimichna Tekhnologiya, 2013, no. 2(21), pp. 156-161. (in Russian).

2. Krutko I., Kaulin V. Teoretychni peredumovy vykorystann'ya kam'yanovugil'nogo peku yak polimernogo materialu [Theoretical preconditions of the use of coal tar pitch as a polymeric material]. Naukovi Pratsi DonNTU, Seriya: Khimiya i Khimichna Tekhnologiya, 2010, no. 15(163), pp. 103-107. (in Ukrainian).

3. Krutko I., Kaulin V., Satsiuk K. Reologichni doslidzhenn'ya modyfikovanykh kam'yanovugil'nykh pekiv [Rheological investigations of modified coal tar pitches]. Naukovi Pratsi DonNTU, Seriya: Khimiya i Khimichna Tekhnologiya, 2011, no. 16(184), pp. 150-158. (in Ukrainian). 
4. Lee S.T., Park C.B., Foam extrusion: principles and practice. CRC Press, 2014. 624 p.

5. Bledzki A.K., Faruk O. Injection moulded microcellular wood fibre-polypropylene composites. Composites Part A: Applied Science and Manufacturing, 2006, vol. 37, pp. 1358-1367.

6. Douibi A., Gouissem L., Guessoum M., Benachour D. Effect of PVC resin and its additives on the decomposition temperature of a chemical blowing agent (azobisformamide). International Journal of Engineering and Technology, 2014, vol. 14 , no. 2 , pp. $60-64$.

7. Zweifel H., Maier R.D., Schiller M., Dobavki $k$ polimeram (spravochnik) [Additives to polymers: a handbook]. Professiya Publishers, St. Petersburg, 2010. 1142 p. (in Russian).

8. Vlasov S.V., Kandyrin L.B., Kuleznev V.N., Osnovy tekhnologii pererabotki plastmass [Fundamentals of plastics processing technology]. Khimiya Publishers, Moscow, 2004. 600 p. (in Russian).

9. Reyes-Labarta J.A., Marcilla A. Kinetic study of the decompositions involved in the thermal degradation of commercial azodicarbonamide. Journal of Applied Polymer Science, 2008, vol. 107, pp. 339-346.

10. Petchwattana N., Covavisaruch S. Influences of particle sizes and contents of chemical blowing agents on foaming wood plastic composites prepared from poly(vinyl chloride) and rice hull. Materials and Design, 2011, vol. 32, pp. 2844-2850.

11. Al-Maliki Tahsin Ali Saki Vliyanie sostava zhestkikh polivinilkhloridnykh kompozitsiy na kinetiku vspenivaniya azodikarbonamidom [Influence of rigid polyvinylchloride composites composition on the kinetics of foaming by azodicarbonamide]: thesis for the degree of Candidate of Technical Sciences, Moscow State University of Fine Chemical Technologies, Moscow, 2016. (in Russian).

12. Vasin A.Ya., Makarov G.V., Marinina L.K., Yakusheva Z.A. Kinetika termicheskogo razlozheniya azosoedinenii [Kinetics of thermal decomposition of azo compounds]. Izvestiya Vuzov SSSR «Khimiya i Khimicheskaya Tekhnologiya», 1980, vol. 23, no. 9, pp. 1070-1074. (in Russian).

13. Gmyzina R.N., Mishina I.M., Pugacheva L.A., Vspenivayushchie agenty dl'ya polivinilkhloridnyh penoplastov [Blowing agents for PVC foams]. NIITEHKHIM Publishers, Moscow, 1984. 42 p. (in Russian). 